\title{
PHOTOSYNTHETIC PIGMENTS AND HUMIC ACIDS IN TROPICAL COASTAL BOARD ECOSYSTEMS
}

\section{PIGMENTOS FOTOSINTETICOS Y ACIDOS HUMICOS EN ECOSISTEMAS COSTEROS TROPICALES}

\author{
P. Perumal \\ P. Subramanian \\ Centre of Advanced Study in Marine Biology \\ Annamalai University \\ Parangipettai - 608502 \\ India
}

Perumal, P. and Subramanian, P. Photosynthetic pigments and humic acids in tropical coastal board ecosystems. Pigmentos fotosintéticos y ácidos húmicos en ecosistemas costeros tropicales. Ciencias Marinas, 15(2): 67-77, 1989.

\begin{abstract}
Spatial variations in the dissolved and particulate humic acids and photosynthetic pigment concentrations along the coastal waters of the Vellar-Coleroon estuarine complex (east coast of India) were estimated, as an index to assess the fertility of water bodies in this area. Generally in all the stations, particulate humic acid (PHA) accounted for the bulk of concentrations among the two fractions. The humic acid concentrations were correlated with chlorophylls, phaeopigments, salinity and other parameters and their relationships are discussed.
\end{abstract}

\section{RESUMEN}

Se estimaron variaciones espaciales en los ácidos húmicos disueltos y particulados y concentraciones de pigmento fotosintético a lo largo de las aguas costeras del complejo estuarino Vellar-Coleroon (costa oriental de la India), como un indice para evaluar la fertilidad de los cuerpos de agua en esta zona. En general, en todas las estaciones el ácido húmico particulado (PHA) resultó ser la mayor parte de las concentraciones entre las dos fracciones. Las concentraciones de ácido húmico fueron correlacionadas con clorofilas, feopigmentos, salinidad y otros parámetros y se discuten sus relaciones.

\section{INTRODUCTION}

In a natural environment, various materials like mangrove leachates, metabolites of plants and animals, dead and decaying organisms and weeds get decomposed by microbial action and autolysis and would get derived mostly as humic substances. They contribute an appreciable fraction of coloured substances (Gelbstoff) present in coastal water. It is generally assumed that the organic matter in natural water ranges in concentrations from 0.1 to $10 \mathrm{mg} / 1$ (Stumm and Morgan, 1970). On an average about $60-80 \%$ of this organic

\section{INTRODUCCION}

En un ambiente natural, varios materiales como lixiviadores de mangles, metabolitos de plantas y animales, organismos muertos $\mathrm{y}$ en putrefacción y maleza son descompuestos por acción microbiana y autólisis y derivarían principalmente en sustancias húmicas. Estos constituyen una fracción considerable de las sustancias coloreadas (Gelbstoff) presentes en aguas costeras. Por lo general, se supone que el material orgánico en aguas naturales está presente en concentraciones que van de 0.1 a $10 \mathrm{mg} / \mathrm{l}$ (Stumm y Morgan, 1970). En prome- 
Perumal, P. and Subramanian, P.- Photosynthetic pigments and humic acids

matter consists of humic acid. In spite of the same operational definition of marine and terrestrial humic acid, they were found to differ in their elemental, isotopic and spectroscopic properties. The lignin found only in vascular plants is considered a major source for the terrestrial humic acid, whereas the autochthonous organic matter is the precursor for the formation of marine humic acids. The melanoidins were found to resemble closely the marine humic acids, whereas the synthetic polymers resemble the terrestrial humic acids (Christman and Gjessing, 1983).

The humic substance performs many important functions in natural waters such as carriers of elements, scavenging, leaching and dissolution of minerals and sediment formation. As a result of accumulation of organic matter, an anaerobic condition is developed with the formation of hydrogen sulphide and low redox potential, because $\mathrm{H}_{2} \mathrm{~S}$ serves as an electron donor for the photosynthetic purple and green sulphur bacteria during the process of assimilation of $\mathrm{CO}_{2}$ and they flourish in that area. Because of the growth promoting action of humic acids, they are used as soil extract in the preparation of growth medium of phytoplankton culture. Prakash and Rashid (1968) state that sedimentary humic acids prevent the formation of insoluble metal salts and thereby stimulate the multiplication of phytoplankton. Together with the concentration of pigments and humic acids and other factors like dissolved organic substances, nutrients, dissolved oxygen the waters of a biotope will evolve within, a potential index of fertility suitable for the growth of phytoplankton, which will have a bearing on secondary production and in turn on the commercial fishery resources of that locale. Hence, the present study was initiated to assess the concentration of these important factors in Porto Novo waters. The naturally occurring proportions of particulate and dissolved fractions of humic acids and the relationship of phytoplankton production were investigated.

\section{MATERIALS AND METHODS}

The water samples from 16 places during 3-9 October, 1983 in the vicinity of the dio, alrededor de $60-80 \%$ de este material orgánico consiste de ácido húmico. A pesar de que la definición operacional es la misma para el ácido húmico marino y terrestre, se encontraron diferencias en sus propiedades elementales, isotópicas y espectroscópicas. La lignina encontrada sólo en plantas vasculares se considera una fuente importante de ácido húmico terrestre, mientras que la materia orgánica autóctona es la precursora para la formación de ácidos húmicos marinos. Se encontró que las melanoidinas son muy similares a los ácidos húmicos marinos, mientras que los polímeros sintéticos se parecen a los ácidos húmicos terrestres (Christman y Gjessing, 1983).

Las sustancias húmicas desempeñan muchas funciones importantes en aguas naturales, tales como la transportación de elementos, lixiviación y disolución de minerales y formación de sedimentos. Como resultado de la acumulación de material orgánico, se desarrolla una condición anaerobia con la formación de sulfuro de hidrógeno y bajo potencial redox, ya que el $\mathrm{H}_{2} \mathrm{~S}$ sirve de donador de electrones a las bacterias fotosintéticas púrpuras y verdes del azufre durante el proceso de asimilación de $\mathrm{CO}_{2}$ y que éstas prosperan en esa zona. A causa de la acción promotora de crecimiento de los ácidos húmicos, se usan como extracto de tierra en la preparación del medio de crecimiento para el cultivo de fitoplancton. Prakash and Rashid (1968) afirman que los ácidos húmicos sedimentarios impiden la formación de sales metálicas insolubles y aś́ estimulan la multiplicación del fitoplancton. La concentración de pigmentos y ácidos húmicos y otros factores como sustancias orgánicas disueltas, nutrientes, oxígeno disuelto en el cual las aguas de un biotopo se desarrollarán y un indice potencial de fertilidad adecuado para el crecimiento del fitoplancton, tendrán un alcance en la producción secundaria y por ende en los recursos pesqueros comerciales de esa localidad. Por lo tanto, se inició el presente estudio para evaluar la concentración de estos importantes factores en las aguas de Porto Novo. Se investigaron las proporciones de ocurrencia natural de fracciones de ácido húmico particulado y disuelto aś́ como la relación de producción fitoplanctónica. 
Perumal, P. and Subramanian, P.- Photosynthetic pigments and humic acids

Vellar-Coleroon estuarine complex and the neritic province of the Bay of Bengal were collected using clean plastic containers. The containers were rinsed with the same sampling water. The water and atmospheric temperature, salinity and dissolved oxygen level of the sampling sites were also observed and recorded.

To estimate the dissolved humic acid (DHA) and particulate humic acid (PHA), the modified Kononova method (1966) was used (Hair and Bassett, 1973). A preservative was used $\mathrm{CCL}^{4}(2 \mathrm{ml} / 250 \mathrm{ml})$ soon after collection to avoid the denaturing of DHA and PHA fractions due to the time lag between collection and anaiysis (Shanmukhappa, 1984). The concentrations of chlorophylls $a$, $b$, carotenoids, phaeopigments and bacteriochlorophylls $a, c, d$ were estimated adopting the standard methods of Strikland and Parsons (1972) and Takahashi and Ichimura (1968).

\section{AREA OF STUDY}

The Vellar-Coleroon estuarine complex $\left(11^{\circ} 29^{\prime} \mathrm{N}\right.$ latitude, $79^{\circ} 46^{\prime} \mathrm{E}$ longitude) is situated on the east coast of India (Bay of Bengal), where they support a luxuriant mangrove ecosystem spread over an area of about $14 \mathrm{~km}^{2}$. This ecosystem experiences semidiurnal tides. The usual tidal amplitude is one meter. In this unique locale the different landscapes and varied ecosystems meet. The station sites were selected representatively (e.g. near salt pans, oyster beds, pen culture area, etc.) for sampling. The humic acids provide the essential elements required for phytoplankton assimilation during photosynthesis and hence the higher productivity was observed in the mangroves (Sundararaj and Krishnamurthy, 1973). The litter production from this mangrove was estimated to be 7.46 tons/ha/yr (Subramanian et al., 1984), which on degradation yields tannic acid, carbonic acid and humic acid, which play an active role in dissolving calcareous materials (molluscan shell, crustacean exoskeleton, etc.). This will add calcium carbonate and phosphate level in water, which are essential for moulting and growth of crustaceans and molluscs.

\section{MATERIALES Y METODOS}

Se colectaron muestras de agua de 16 localidades durante el período del 3 al 9 de octubre de 1983 en la región del complejo estuarino Vellar-Coleroon y de la provincia neritica de la Bahía de Bengal, usando recipientes limpios de plástico. Los recipientes fueron enjuagados con la misma agua del muestreo. También se observaron y registraron la temperatura del agua y la atmosférica, la salinidad y el nivel de oxígeno disuelto en las estaciones de muestreo.

Para estimar el ácido húmico disuelto (DHA) y ácido húmico particulado (PHA), se usó el método de Kononova (1966) modificado (Hair y Bassett, 1973). Poco después del muestreo, se utilizó $\mathrm{CCL}^{4}(2 \mathrm{ml} / 250 \mathrm{ml})$ para preservar y así evitar la desnaturalización de las fracciones de DHA y PHA en el intervalo entre la colecta y análisis (Shanmukhappa, 1984). Se estimaron las concentraciones de clorofilas $a, b$, carotenoides, feopigmentos y bacterioclorofilas $a, c, d$ usando los métodos normales de Strickland y Parsons (1972) y Takahashi e Ichimura (1968).

\section{AREA DE ESTUDIO}

El complejo estuarino Vellar-Coleroon (11029'N latitud, $79^{\circ} 46^{\prime} \mathrm{E}$ longitud) está localizado en la costa oriental de la India (Bahía de Bengal), donde hay un ecosistema frondoso de manglares que cubre un área de aproximadamente $14 \mathrm{~km}^{2}$. Este ecosistema experimenta mareas semidiurnas. La amplitud normal de la marea es de un metro. En este sitio único se juntan paisajes diferentes y ecosistemas diversos. Las estaciones de muestreo fueron escogidas de manera representativa (e.g. cerca de salinas, región ostrícola, área de cultivo de encierro, etc.). Los ácidos húmicos proporcionan los elementos necesarios para la asimilación del fitoplancton durante la fotosintesis y por lo tanto, la productividad más alta se observó en los manglares (Sundararaj y Krishnamurthy, 1973). La producción de hojarasca de este manglar se estimó en 7.46 ton/ha/año (Subramanian et al., 1984), que al descomponerse produce ácido tánico, ácido carbónico y ácido 


\section{RESULTS}

The particulate humic acid fraction in the samples was always higher than dissolved humic acid for the same site. A significant positive correlation was observed between both forms of humic acid (PHA and DHA) and phaeopigment concentration (Table I). The densely populated areas of benthos such as the oyster bed and the pen culture region also showed higher concentrations of humic acid.

The average concentrations (ppm) of humic acid among different stations of each biotope were as follows:

$\begin{array}{clcr}\text { NO. } & \text { BIOTOPE } & \text { DHA } & \text { PHA } \\ 1 & \text { Mangroves } & 7.95 & 18.08 \\ 2 & \text { Backwater } & 4.51 & 12.27 \\ 3 & \text { Coleroon Estuary } & 5.84 & 10.46 \\ 4 & \text { Vellar Estuary } & 3.89 & 10.39 \\ 5 & \text { Sea } & 5.34 & 8.34\end{array}$

From the observed concentrations from mangroves and the nearby waterways, the schematic pattern of flow of humic acids is depicted below:

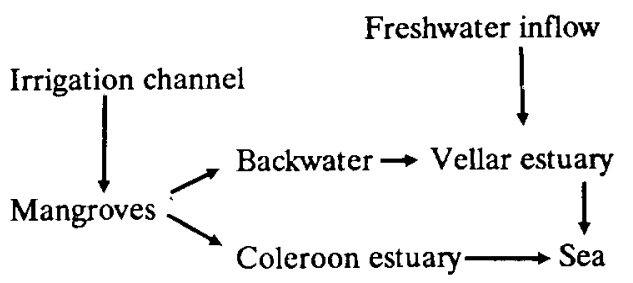

Among the particulate concentration analysed between the two river mouths (Vellar and Coleroon), Coleroon river mouth showed a higher concentration of PHA. The chlorophyll $a$ and the phaeopigment concentrations showed negative correlation. The grouped range of humic acid, pigment concentration and hydrographical parameters are given in Table II (for locations of sampling sites refer to Fig. 1 of the map). The salinity, phaeopigments, chlorophyll $a$ and two fractions of humic acids in different stations are depicted in Figure 2. The concentration of humic acid húmico, que a su vez juegan un papel activo en la disolución de materiales calcáreos (concha de molusco, dermatoesqueleto de crustáceo, etc.). Esto hace aumentar el nivel de carbonato de calcio y fosfato en el agua, que son necesarios para la muda y crecimiento de crustáceos y moluscos.

\section{RESULTADOS}

La fracción del ácido húmico particulado en las muestras fue siempre mayor que la del ácido húmico disuelto para la misma localidad. Se observó una significativa correlación positiva entre ambas formas de ácido húmico (PHA y DHA)y las concentraciones de feopigmentos (Tabla I). Las áreas densamente pobladas de bentos como son la región ostrícola y la región de cultivo de encierro, también mostraron concentraciones altas de ácido húmico.

Las concentraciones medias (ppm) de ácido húmico en las diferentes estaciones de cada biotopo fueron las siguientes:

$\begin{array}{clcr}\text { NO. } & \text { BIOTOPO } & \text { DHA } & \text { PHA } \\ 1 & \text { Manglares } & 7.95 & 18.08 \\ 2 & \text { Agua estancada } & 4.51 & 12.27 \\ 3 & \text { Estuario Coleroon } & 5.84 & 10.46 \\ 4 & \text { Estuario Vellar } & 3.89 & 10.39 \\ 5 & \text { Mar } & 5.34 & 8.34\end{array}$

El patrón esquemático del flujo del ácido húmico, a partir de las concentraciones observadas en los manglares y las vías fluviales cercanas, se representa por:

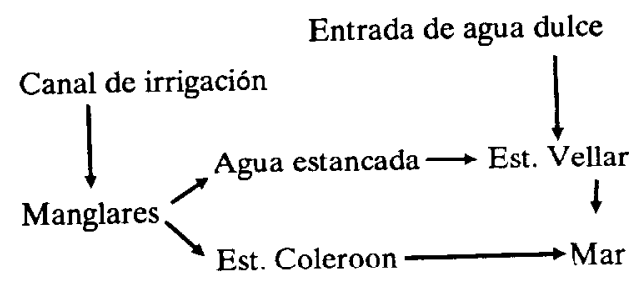

En el análisis de concentración de partículas realizado entre las dos bocas (Vellar y Coleroon), se observó una concentración mayor de PHA en la boca del río Coleroon. 
Perumal, P. and Subramanian, P.- Photosynthetic pigments and humic acids

Table I. Correlation coefficient matrix among different parameters.

Tabla I. Matriz de coeficiente de correlación entre los diferentes parámetros.

\begin{tabular}{lcccccc}
\hline & PHA & DHA & Salinity & Chl. $a$ & Ba.Chl. $a$ & Phaeopigment \\
\hline PHA & - & $0.5361^{*}$ & -0.4478 & -0.1036 & -0.3816 & $0.7742^{*}$ \\
DHA & - & - & -0.1845 & -0.0701 & -0.0473 & 0.2715 \\
Salinity & - & - & - & -0.2496 & 0.4451 & -0.2693 \\
Chl. $a$ & - & - & - & - & $0.8492^{*}$ & -0.2421 \\
Ba.Chl. $a$ & - & - & - & - & - & -0.2952 \\
Phaeopigment & - & - & - & - & - & - \\
\hline
\end{tabular}

$* \mathrm{P}<0.05$

along the two riverine courses is represented in Figure 3.

\section{DISCUSSION}

The observed higher concentration of particulate humic acids in all the 16 stations could be attributed to the dynamic nature of the environment and the active involvement of comminuting organisms in the processes of litter degradation, churning up the organic matter due to tidal ebb and flow, etc. The lower concentration of DHA could reveal the frequent washing and dilution by tidal water as well as precipitation by higher saline water. The negative correlation found between the humic acid concentration and salinity would show that most of the humic acids of this region are derived from freshwater run-off, besides mangrove litter and leachates and autochthonous sources. Since all the sampling sites are within the Vellar-Coleroon estuarine complex, the influence of the mangroves upon adjoining waters was significant. The high seston content leads to considerable production of detritus (up to $1 \mathrm{~g}$ /litre; Krishnamurthy and Sundararaj, 1973).

The arrived positive correlation between both forms of humic acid and phaeopigments (Table II) was due to the rich phaeopigments in areas where heavy grazing by zooplankton or filter feeders occur. This would account for high humic acid concentrations in the oyster
Las concentraciones de clorofila $a$ y el feopigmento mostraron una correlación negativa. $\mathrm{El}$ intervalo agrupado de ácido húmico, concentración de pigmento y parámetros hidrográficos se presentan en la Tabla II (para la localización de las estaciones de muestreo, ver Fig. 1). La salinidad, los feopigmentos, la clorofila $a$ y dos fracciones de ácido húmico para estaciones diferentes, se presentan en la Figura 2. La concentración del ácido húmico a lo largo de los dos cursos fluviales se presenta en la Figura 3.

\section{DISCUSION}

La alta concentración observada de ácidos húmicos particulados en las 16 estaciones, se puede atribuir a la naturaleza dinámica del medio ambiente y a la participación activa de organismos en el proceso de descomposición de la hojarasca, removiendo el material orgánico debido al flujo y reflujo de marea, etc. La baja concentración de DHA podría indicar el frecuente lavado y dilución por las mareas así como la precipitación de aguas más salinas. La correlación negativa encontrada entre la concentración de ácido húmico y la salinidad indicaría que la mayoría de los ácidos húmicos de esta región se derivan de escurrimientos de agua dulce aparte de hojarasca y lixiviadores del mangle y fuentes autóctonas. $\mathrm{Ya}$ que las estaciones de muestreo están situadas dentro del complejo estuarino VellarColeroon, la influencia del manglar sobre las 


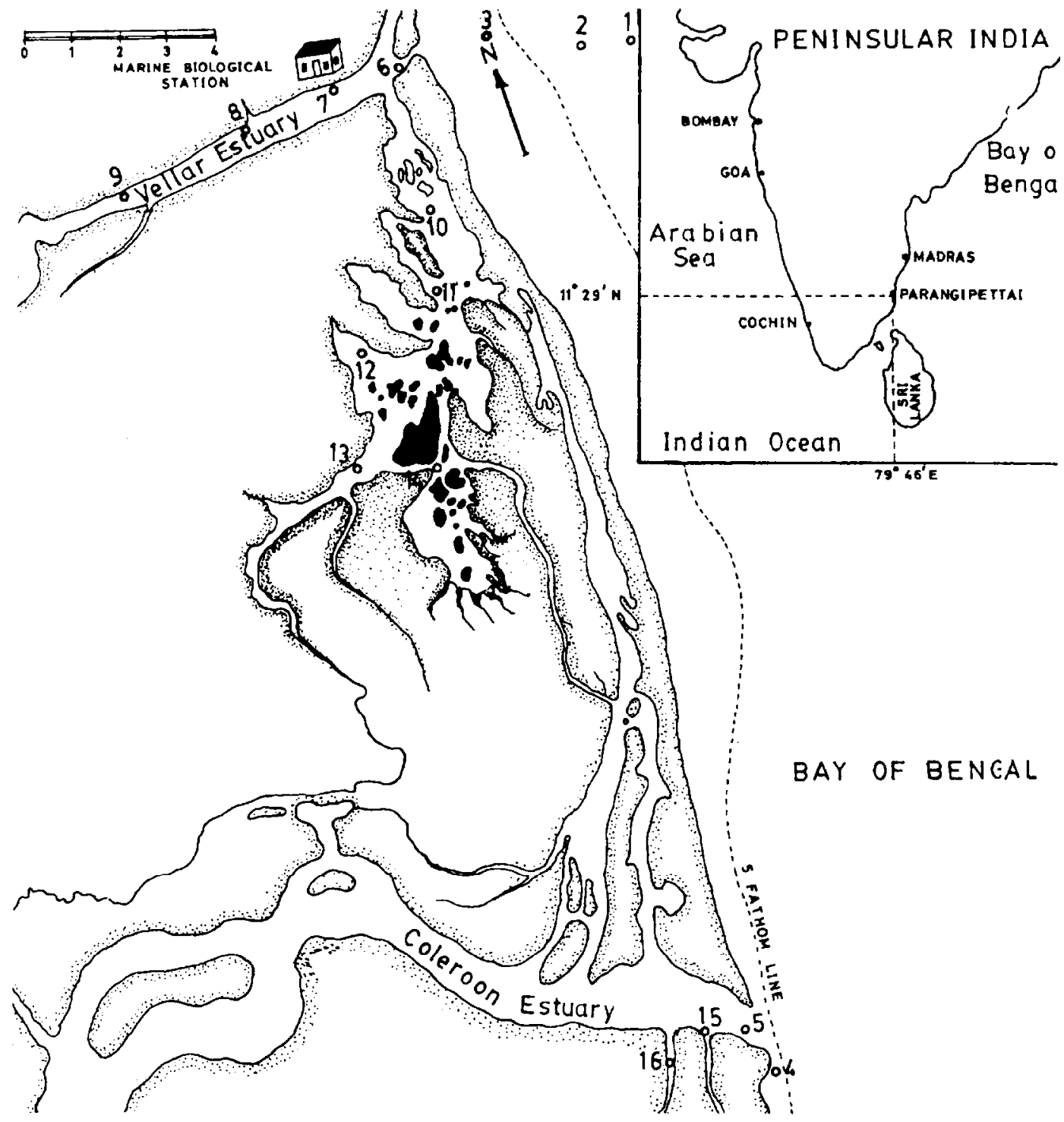

Figure 1. Locations of sampling stations.

Figura 1. Localización de las estaciones de muestreo.

bed region, where the accumulation of organic matter and release of excretory products were high. Moreover, the oysters remove the particulate matter from the water column by filtration (biodeposition). After digestion they are excreted as faecal pellets which accumulate in and around the oyster bed region. The ultimate degradation of this organic matter aguas adyacentes fue significativa. El alto contenido de seston resulta en una considerable producción de detrito (hasta $1 \mathrm{gm} / \mathrm{litro}$; Krishnamurthy y Sundararaj, 1973).

La correlación positiva entre las dos formas de ácido húmico y los feopigmentos (Tabla II) se debió a los ricos feopigmentosen 
Perumal, P. and Subramanian, P.- Photosynthetic pigments and humic acids

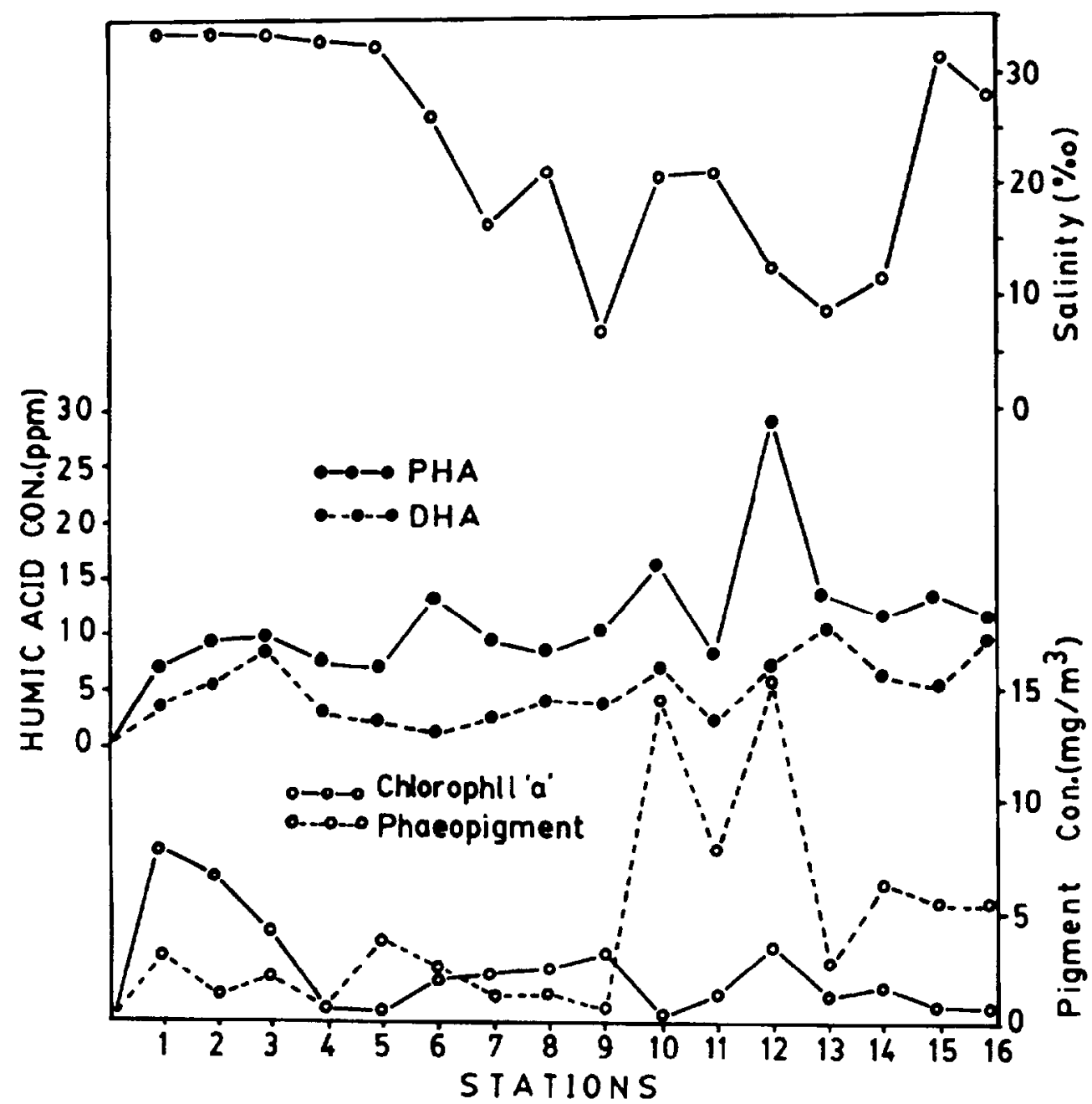

Figure 2. Concentrations of dissolved and particulate humic acids, salinity, chlorophyll $a$ and phaeopigments, 3-9 October, 1983.

Figura 2. Concentraciones de ácido húmico disuelto y particulado, salinidad, clorofila $a$ y feopigmentos, 3-9 de octubre de 1983.

would result in higher humic acid concentration in this area. In the pen culture region the culturist dumping a lot of leaved branches of trees to provide shade as well as microbially infested food to prawns, apart from artificial feed, results in progressive biodegradation and release of humic substances on decay. These materials along with the excretory products of prawn, degrade and generate huge amounts of humic materials. The excessive load of nutrients and faecal material due to the denizens, áreas donde ocurre mucho pastoreo por zooplancton o filtroalimentadores. Esto explica las altas concentraciones del ácido húmico en la región ostrícola, donde la acumulación de materia orgánica y liberación de productos excretorios fueron altos. Asimismo, las ostras reducen el material particulado de la columna de agua por filtración (biodeposición). Después de la digestión son excretados como "pellets" fecales que se acumulan en y alrededor de la región ostrícola. La última 
Perumal, P. and Subramanian, P.- Photosynthetic pigments and humic acids

Table II. The humic acids and pigment concentrations and the environmental parameters of selected sites.

Tabla II. Acidos húmicos, concentraciones de pigmentos y los parámetros ambientales de sitios seleccionados.

\begin{tabular}{|c|c|c|c|c|c|}
\hline \multirow{2}{*}{$\begin{array}{l}\text { Sl. } \\
\text { No. }\end{array}$} & & \multicolumn{3}{|c|}{ Ranges } & \multirow{2}{*}{$\begin{array}{l}\text { Total number of } \\
\text { stations in the } \\
\text { same range }\end{array}$} \\
\hline & & Minimum & & Maximum & \\
\hline 1) & DHA (ppm) & $\begin{array}{l}1 \\
4.1 \\
8.1\end{array}$ & $\begin{array}{l}\text { to } \\
- \\
-\end{array}$ & $\begin{array}{r}4.0 \\
8.0 \\
12.0\end{array}$ & $\begin{array}{l}7 \\
6 \\
3\end{array}$ \\
\hline 2) & PHA (ppm) & $\begin{array}{r}5.1 \\
13.1 \\
21.1\end{array}$ & $\begin{array}{l}- \\
- \\
-\end{array}$ & $\begin{array}{l}13.0 \\
21.0 \\
29.0\end{array}$ & $\begin{array}{r}11 \\
4 \\
1\end{array}$ \\
\hline 3) & Chl. $a\left(\mathrm{mg} / \mathrm{m}^{3}\right)$ & $\begin{array}{l}0.1 \\
3.1 \\
6.1\end{array}$ & $\begin{array}{l}- \\
-\end{array}$ & $\begin{array}{l}3.0 \\
6.0 \\
9.0\end{array}$ & $\begin{array}{r}11 \\
3 \\
2\end{array}$ \\
\hline 4) & Ch1. $b\left(\mathrm{mg} / \mathrm{m}^{3}\right)$ & $\begin{array}{l}0.2 \\
2.1 \\
4.1\end{array}$ & $\begin{array}{l}- \\
-\end{array}$ & $\begin{array}{l}2.0 \\
4.0 \\
7.0\end{array}$ & $\begin{array}{l}6 \\
5 \\
5\end{array}$ \\
\hline 5) & Carotenoides (m.s.p.u.) & $\begin{array}{l}0.6 \\
3.1 \\
6.1\end{array}$ & $\begin{array}{l}- \\
- \\
-\end{array}$ & $\begin{array}{l}3.0 \\
6.0 \\
9.0\end{array}$ & $\begin{array}{c}10 \\
5 \\
1\end{array}$ \\
\hline 6) & Ba. Chl. $a\left(\mathrm{mg} / \mathrm{m}^{3}\right)$ & $\begin{array}{r}0.7 \\
5.1 \\
10.1\end{array}$ & $\begin{array}{l}- \\
-\end{array}$ & $\begin{array}{r}5.0 \\
10.0 \\
15.0\end{array}$ & $\begin{array}{r}11 \\
2 \\
3\end{array}$ \\
\hline 7) & Ba. Chl. $c\left(\mathrm{mg} / \mathrm{m}^{3}\right)$ & $\begin{array}{l}0.1 \\
4.1 \\
8.1\end{array}$ & $=$ & $\begin{array}{r}4.0 \\
8.0 \\
12.0\end{array}$ & $\begin{array}{c}15 \\
0 \\
1\end{array}$ \\
\hline 8) & $\mathrm{Ba} . \mathrm{Chl} . d\left(\mathrm{mg} / \mathrm{m}^{3}\right)$ & $\begin{array}{l}0.9 \\
4.1 \\
8.1\end{array}$ & $\begin{array}{l}- \\
-\end{array}$ & $\begin{array}{r}4.0 \\
8.0 \\
12.0\end{array}$ & $\begin{array}{r}12 \\
3 \\
12\end{array}$ \\
\hline 9) & Phaeopigments $\left(\mathrm{mg} / \mathrm{m}^{3}\right)$ & $\begin{array}{r}0.5 \\
5.1 \\
10.1\end{array}$ & $=$ & $\begin{array}{r}5.0 \\
10.0 \\
16.0\end{array}$ & $\begin{array}{r}10 \\
4 \\
2\end{array}$ \\
\hline 10) & Pigment index & $\begin{array}{l}1.0 \\
3.1 \\
6.1\end{array}$ & $\begin{array}{l}- \\
-\end{array}$ & $\begin{array}{r}3.0 \\
6.0 \\
10.0\end{array}$ & $\begin{array}{l}9 \\
6 \\
1\end{array}$ \\
\hline 11) & Salinity $(\% / 00)$ & $\begin{array}{r}7.5 \\
16.5 \\
25.5\end{array}$ & $\begin{array}{l}- \\
-\end{array}$ & $\begin{array}{l}16.5 \\
25.5 \\
35.5\end{array}$ & $\begin{array}{l}5 \\
3 \\
8\end{array}$ \\
\hline 12) & Dissolved oxygen (ml.1-1) & $\begin{array}{l}3.0 \\
4.5 \\
6.0\end{array}$ & $\begin{array}{l}- \\
-\end{array}$ & $\begin{array}{l}4.5 \\
6.0 \\
7.5\end{array}$ & $\begin{array}{l}9 \\
4 \\
3\end{array}$ \\
\hline 13) & Water temperature $\left({ }^{\circ} \mathrm{C}\right)$ & $\begin{array}{l}25 \\
27 \\
29\end{array}$ & $=$ & $\begin{array}{l}27 \\
29 \\
31\end{array}$ & $\begin{array}{l}1 \\
6 \\
6\end{array}$ \\
\hline
\end{tabular}




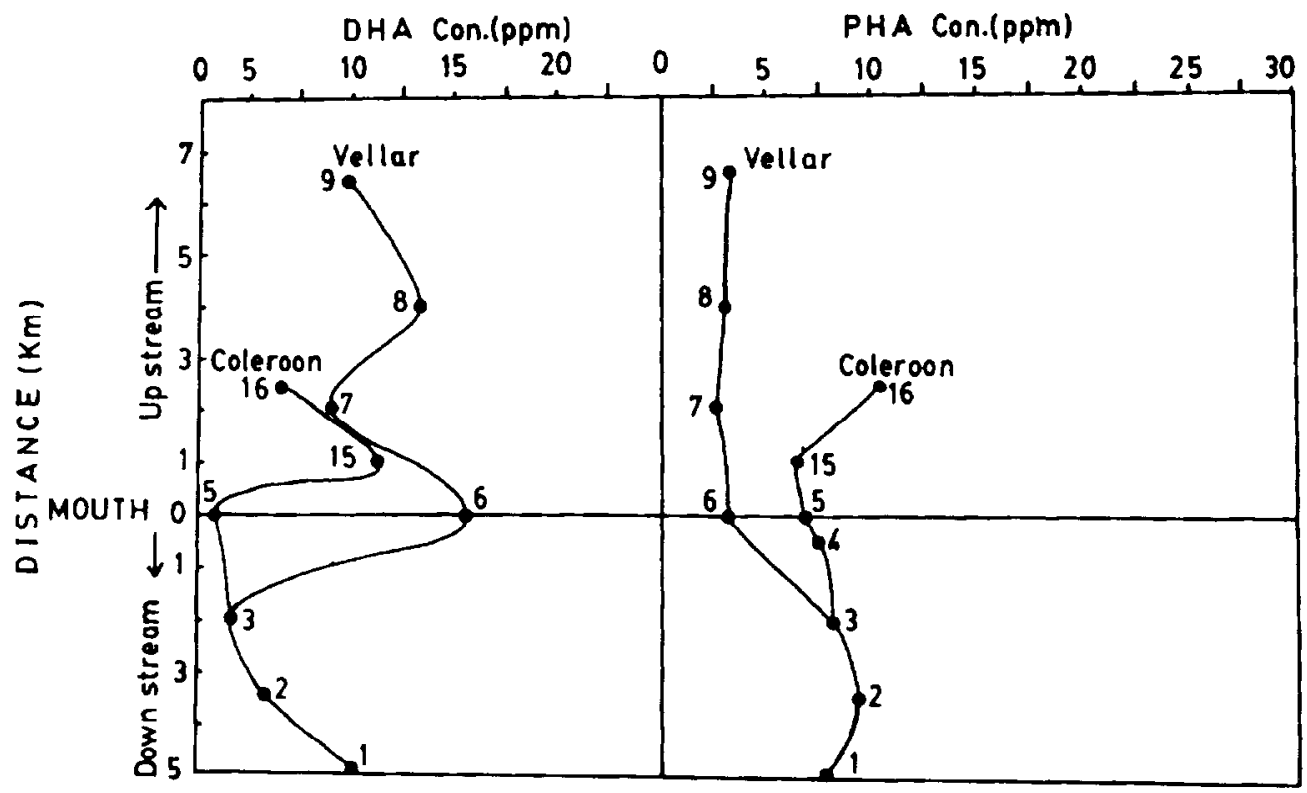

Figure 3. Concentrations of dissolved and particulate humic acids along the Vellar and Coleroon riverine courses.

Figura 3. Concentraciones de ácido húmico disuelto y particulado a lo largo de los cursos fluviales Vellar y Coleroon.

get decomposed and leached as humic substances. Thus recorded the maximum amount of humic acid (DHA7.0 ppm, PHA $28.8 \mathrm{ppm}$ ). Photosynthetic sulphur bacteria flourish well in this area because of anaerobic conditions created due to fine organic detritus and availability of $\mathrm{H}_{2} \mathrm{~S}$ as electron donor for $\mathrm{CO}_{2}$ assimilation (Krishnamurthy et al., 1986; Pfennig, 1978). The humic materials present in the colloidal state reduce any toxicity through uptake of toxic materials from its environs. Similarly they adhere the element nutrients also. By way of releasing the adhered nutrient elements and metals slowly to the surroundings and help algal cells for greater production. The high PHA concentration observed in the Coleroon mouth may be due to the precipitation of dissolved humic acid while the freshwater admixes with the sea water. It could be reflected in the higher benthic production observed in the area (Jagadeesan, 1986). degradación de esta materia orgánica resultaría en concentraciones mayores de ácido húmico en esta zona. En la región de cultivo de encierro, las descargas del culturista, compuestas de ramas de árboles llenas de hojas para dar sombra, comida de camarones que está infestada de microbios y comida artificial, resulta en biodegradaciones progresivas y en la liberación de sustancias húmicas al descomponerse. Estas materias, junto con los productos excretorios del camarón, se degradan y generan muchas materias húmicas. La carga excesiva de nutrientes y de material fecal producido por los habitantes son descompuestos y lixiviados como sustaricias húmicas. Aś́, se registró la cantidad máxima de ácido húmico (DHA $7.0 \mathrm{ppm}$, PHA $28.8 \mathrm{ppm}$ ). Bacterias fotosintéticas del azufre abundan en esta área por la condición anaerobia creada debido al detrito orgánico fino y a la disponibilidad de $\mathrm{H}_{2} \mathrm{~S}$ como donador de electrones para la asimilación de $\mathrm{CO}_{2}$ (Krishnamurthy et 
The chlorophyll $a$ and phaeopigment of the samples analysed showed negative correlation, because the phaeopigments are the chlorophyll degraded products and need to be taken as a direct index of intensive grazing by herbivores in the area. The recorded higher values of bacteriochlorophylls $(a, c$ and $d)$ at the mangrove stations were mainly due to photosynthetic sulphur bacteria. A similar observation was also reported by Panneerselvam et al. (1979). The yellow-green pigment indices (at 430 and $665 \mathrm{~nm}$ ) of phytoplankton in this study area varied between 0.4 and 2.86 . The encountered low ratio $(>1.2)$ indicates the dominance of green pigments especially in the Vellar estuary and the neighbouring neritic province of Bay of Bengal. The higher ratio observed at Coleroon $(<2.2)$ indicates the extensive occurrence of yellow pigmented diatoms, dinoflagellates, senescent phytoplanktonic materials and also photosynthetic bacteria of mangroves, carried through semidiurnal tides (Subramanian, 1987).

\section{ACKNOWLEDGEMENTS}

We are thankful to Prof. K. Krishnamurthy, Director, Centre of Advanced Study in Marine Biology, for encouragement and facilities; the University Grants Commission and the Ministry of Environment and Forests (ERC), Government of India, New Delhi, for financial assistance.

\section{LITERATURA CITADA}

Christman, R.F. and Gjessing, E.T. (1983). Aquatic and terrestrial humic materials. Michigan, Ann Arbor, Sci. Publ., pp. 538.

Hair, M.E. and Bassett, C.R. (1973). Dissolved and particulate humic acid in an east coast estuary. Est. \& Coast. Mar. Sci., 1: $107-111$.

Jagadessan, P. (1986). Studies on environmental inventory of the marine zone of Coleroon Estuary and inshore waters of Pazhayaru, Southeast coast of India. Ph.D. Thesis, Annamalai University, p. 277. al., 1986; Pfennig, 1978). Las materias húmicas presentes en estado coloidal reducen cualquier toxicidad por medio de la asimilación de materiales tóxicos del medio ambiente. También se les adhieren elementos nutrientes. Liberando lentamente los elcmentos nutrientes y metales adheridos hacia el medio ambiente, ayudan a la mayor producción celular de algas. La alta concentración de PHA observada en la boca del Coleroon se podría deber a la precipitación de ácido húmico disuelto al tiempo que el agua dulce se mezcla con el agua de mar. Se podría reflejar en la mayor producción de bentos observada en la zona (Jagadeesan, 1986).

La clorofila $a$ y el feopigmento de las muestras analizadas demostraron una correlación negativa, ya que los feopigmentos son los productos degradados de clorofila y deben tomarse como un indice directo de pastoreo intensivo por los herbívoros en la zona. Los valores más altos registrados de bacterioclorofilas $(a, c$ y $d$ ) en las estaciones del manglar se debieron principalmente a bacterias fotosintéticas del azufre. Panneerselvam et al. (1979) también reportaron observaciones similares. Los indices del pigmento amarilloverde (a 430 y $665 \mathrm{~nm}$ ) de fitoplancton en esta área de estudio varió entre 0.4 y 2.86 . La baja razón encontrada $(>1.2)$ indica la dominancia de los pigmentos verdes, especialmente en el estuario de Vellar y la provincia nerítica adyacente de la Bahía de Bengal. La razón más alta observada en Coleroon ( $<2.2)$ indica la gran ocurrencia de diatomeas con pigmento amarillo, dinoflagelados, materia fitoplanctónica senescente y también de bacterias fotosintéticas de manglares, acarreadas por mareas semidiurnas (Subramanian, 1987).

\section{AGRADECIMIENTOS}

Agradecemos al Prof. K. Krishnamurthy, Director, Centre of Advanced Study in Marine Biology, por su estímulo y uso de instalaciones; al University Grants Commission y Ministry of Environment and Forests (ERC), Gobiernode la India, Nueva Delhi, por apoyo financiero.

Harris. 
Perumal, P. and Subramanian, P.- Photosynthetic pigments and humic acids

Kononova, M.M. (1966). Soil organic matter. 2nd Edition, Oxford, London, Pergamon Press, pp. 544.

Krishnamurthy, K., Perumal, P. and Palaniappan, R. (1986). Photosynthetic bacteria from the coastal board ecosystems. Curr. Sci., 55(13): 617-620.

Krishnamurthy, K. and Sundararaj, V. (1973). A survey of environmental features in a section of the Vellar-Coleroon estuarine system, South India. Mar. Biol., 23: 229-237.

Panneerselvam, A., Kannan, L. and Krishnamurthy, K. (1979). Photosynthetic pigments in coastal ecosystems. Indian J. Mar. Sci., $8(2): 109-111$.

Pfennig, N. (1978). The photosynthetic bactei ia. R.K. Claytren and W.R. Sistrom (eds.). Chapter 1, General Physiology and Ecology of Photosynthetic Bacteria. New York, V, Plenum Publishing Corporation.

Prakash, A. and Rashid, M. (1968). Influence of humic substances on the growth of marine phytoplankton: Dinoflagellates. Limnol. Oceanogr., 13: 598-606.

Shanmukhappa, H. (1984). The humic acids and elements of biological importance in the sea, estuary and mangroves of Porto Novo, South India. Ph.D. Thesis, Jawaharlal Nehru University, pp. 195.
Strickland, J.D.H. and Parsons, T.R. (1972). A practical hand book of seawater analysis. Bull. Fish. Res. Bd. Canada, 167: 310.

Subramanian, P. (1987). Spatial dstribution of humic acids and planktonic pigments in three rivers and the confluencing Bay of Bengal. J. Environ. Biol., Vol. 8 (2-suppl.), pp. 217-224.

Subramanian, P., Prince Jeyaseelan, M.J. and Krishnamurthy, K. (1984). The nature of biodegradation of vegetation in mangrove ecosystems. Chem. in Ecol, 2: 47-68.

Stumm, W. and Morgan, J.J. (1970). Aquatic chemistry. New York, Wiley Interscience, pp. 583.

Sundararaj, V. and Krishnamurthy, K. (1973). Photosynthetic pigments and primary production. Curr. Sci., 42: 185-189.

Takahashi, M. and Ichimure, S.E. (1968). Vertical distribution and organic matter production of photosynthetic sulfur bacteria in Japanese lakes. Limnol. Oceanogr., 13: 644-655. 